\title{
Modification of AlSi7Mg0.3 alloy by strontium
}

Nataša Náprstková, Sylvia Kuśmierczak, Jaromír Cais.

Faculty of Production Technology and Management, JEPU in Ústí nad Labem. E-mail: naprstkova@ fvtm.ujep.cz

Alloy modifying is common practice for improving the structure of the material. One of often used material, where the modification is used is AlSi7Mg0.3 alloy. And modification of AlSi7Mg0.3 is often realized by strontium. The paper deals with an experiment that was realized at the Faculty of Production Technology and Management of Jan Evangelista Purkyně University in Ústí nad Labem, which dealt with the effect of modifications by strontium on the structure of AISi7Mg0.3. In frame of its experiment were analyzed metallographic samples and were observed structures of unmodified and modified material on the microscope. Was evaluated result of modification on the structure.

Keywords: alloy, modification, silumin, $\mathrm{Sr}$

\section{References}

[1] BOLIBRUCHOVÁ, D., TILLOVÁ, E. Zlievarenské zliatiny Al-Si. ŽU, Žilina: EDIS - vydavatelstvo ŽU, 2005. ISBN 80-8070-485-6

[2] MICHNA, Štefan, LUKÁČ, Ivan, OČENÁČEK, V., KOŘENÝ, R., DRÁPALA, J., SCHNEIDER, H., MIŠKUFOVÁ, A. a kol. Encyklopedie hliníku. Adin, Prešov, 2005, ISBN 80-89041-88-4.

[3] MICHNA, Š., KUŚMIERCZAK, S. Technologie a zpracování hliníkových materiálů. UJEP. Ústí nad Labem, 2008. $152 \mathrm{p}$.

[4] MICHNA, Š., NOVÁ, I. Technologie a zpracování kovových materiálů. Adin, Prešov, 2008, ISBN 978-8089244-38-6

[5] MICHNA, Š. NAPRSTKOVÁ, N. The Mechanical Properties Optimizing of of Al - Si Alloys Precipitation Hardening and the Effect on the Character of the Chip, Acta Metallurgica Slovaca, 3/2011, ISSN-1335-1532

[6] TILlOVA, E., FARKAŠOVA, M., CHALUPOVA, M. The Role of Antimony in Modifying of Al-Si-Cu Cast Aloy, Manufacturing Technology, 2013, Vol.13, No.1, pp. 109-114, ISSN 1213-2489

[7] TILlOVA, E., CHALUPOVA, M., HURTAlOVA, L., DUURINIKOVA, E. Quality control of microstructure in recycled Al-Si cast alloys, Manufacturing Technology, 2011, Vol.11, No.11, pp. 70-76, ISSN 1213-2489

[8] ČSN EN 1796 - Hliník a slitiny hliníku - Odlitky - Chemické složení a mechanické vlastnosti

[9] KALINCOVÁ, D. Skúšanie mechanických vlastností materiálov - prehl’ad meracích metód a zariadení. In proceedings Zvyšovanie efektívnosti vzdelávacieho procesu prostredníctvom inovačných prostriedkov, KEGA 3/6370/08., TU vo Zvolene, Zvolen. 2010, pp. 13-26.

[10] LIPINSKI T. Microstructure and Mechanical Properties of the AlSi13Mg1CuNi Alloy with Ecological Modifier. Manufacturing Technology. 2011, Vol. 11, pp 40-44.

[11] TILlOVA E., CHALUPOVA M., HURTALOVA L., DURINIKOVA, E. Quality Control of Microstructure in Recycled Al-Si Cast Alloys. Manufacturing Technology, 2011, Vol. 11, No. 11, pp. 70-76. ISBN 1213-2489

[12] LIPIŃSKI T. Microstructure and Mechanical Properties of the AlSi13Mg1CuNi Alloy With Ecological Modifier, Manufacturing Technology, 2011, Vol. 11, No. 11, pp.40-44 ISBN 1213-2489, 2011, ISSN 1213-2489

[13] MICHALCOVA, A., VOJTĚCH, D. Structure of rapidly solidified aluminium alloys. Manufacturing Technology, 2012, Vol. 12, No. 13, pp. 166-16, ISSN1213-24891 